\title{
Evaluasi Penampilan Sifat Hortikultura dan Potensi Hasil pada Jagung Manis dan Jagung Ketan
}

\section{Evaluation of Horticultural Character and Potential Yield in Sweet Corn and Waxy Corn}

\author{
Umi Maryamah, Surjono Hadi Sutjahjo", dan Anggi Nindita
}

\author{
Departemen Agronomi dan Hortikultura, Fakultas Pertanian, Institut Pertanian Bogor \\ (Bogor Agricultural University), Jl. Meranti, Kampus IPB Darmaga, Bogor 16680, Indonesia \\ Telp.\&Faks.62-251-8629353 e-mail agronipb@indo.net.id \\ "Penulis untuk korespondensi : surjonohadi@yahoo.co.id
}

Disetujui 16 Januari 2017/ Published Online 24 Januari 2017

\begin{abstract}
The research was aimed to evaluate horticultural character performance and yield potential on sweet corn and waxy corn. The field experiment was conducted at Leuwikopo Teaching Farm and Laboratory of Plant Breeding, Bogor Agricultural University from January to May 2016. The experiment was arranged in augmented design with genotype as factor. The genetic material was consisted of 32 corn genotype and 6 commercial varieties as check. There are 26 genotype of waxy corn and 6 genotype of sweet corn. There are three genotype of waxy corn varieties as check (URI, Kumala, Victoria) and three genotype of sweet corn varieties (Bonanza, Secada, Talenta) as check. Waxy corn and sweet corn genotype elucidated diversity on horticulture characters except ASI (Anthesis Silking Interval). The positive correlation were resulted between ear lenght, ear diameter, ear height, and ear weight to corn productivity. Genotypes of waxy corn which have higher horticultural characteristic and yield potential are JLP16, JWP127, JWP223, JWP21, JWP32, JKP2, and JLL1. The genotype of sweet corn that has higher horticultural characteristic and yield potential is SD3.
\end{abstract}

Keywords: augmented, production, qualitative character, quantitative character

\begin{abstract}
ABSTRAK
Penelitian ini bertujuan untuk mengevaluasi keragaan karakter hortikultura dan potensi hasil dari genotipe jagung manis dan jagung ketan. Percobaan dilaksanakan di Kebun Percobaan Leuwikopo dan Laboratorium Pemuliaan Tanaman, Kampus IPB Dramaga pada bulan Januari sampai dengan Mei 2016. Penelitian menggunakan rancangan augmented dengan faktor tunggal yaitu genotipe jagung. Materi genetik yang digunakan adalah 32 genotipe uji dan 6 genotipe pembanding. Genotipe uji terdiri atas 26 genotipe jagung ketan dan 6 genotipe jagung manis. Genotipe pembanding terdiri atas 3 varietas jagung ketan (URI, Kumala, Victoria) dan 3 varietas hibrida jagung manis (Bonanza, Secada, Talenta). Genotipe jagung ketan dan jagung manis yang diuji menunjukkan keragaman karakter hortikultura kecuali pada karakter ASI (Anthesis Silking Interval). Terdapat korelasi positif yang sangat nyata antara panjang tongkol, diameter tongkol, bobot tongkol, dan bobot biji tongkol ${ }^{-1}$ terhadap produktivitas. Genotipe jagung ketan yang memiliki karakteristik hortikultura dan produktivitas yang baik adalah JLP16, JWP127, JWP223, JWP21, JWP32, JKP2, dan JLL1. Adapun genotipe jagung manis yang memiliki karakteristik hortikultura dan produktivitas yang baik adalah SD3.
\end{abstract}

Kata kunci : augmented, karakter kualitatif, karakter kuantitatif, produksi 


\section{PENDAHULUAN}

Jagung manis merupakan salah satu komoditas hortikultura yang digemari oleh masyarakat karena memiliki rasa yang manis. Jagung manis memiliki kandungan gula yang lebih tinggi dibandingkan dengan jenis jagung lainnya sehingga memiliki rasa yang lebih manis dan sesuai dengan keinginan masyarakat (Syukur dan Rifianto, 2013). Jagung manis umumnya dikonsumsi dalam bentuk jagung muda yang direbus atau dibakar. Kebutuhan akan tersedianya jagung manis semakin meningkat. Data Badan Pusat Statistik (2015) menunjukkan bahwa terjadi peningkatan impor jagung manis sebesar $6.26 \%$ per tahun. Hal ini menandakan bahwa produksi jagung manis nasional belum dapat mencukupi permintaan pasar. Salah satu kendala yang dihadapi yaitu produktivitas jagung manis di dalam negeri yang masih rendah. Produktivitas jagung manis di Indonesia rata-rata 8.31 ton ha ${ }^{-1}$ (Muhsanati et al., 2006) dengan potensi hasil jagung manis mencapai 14-18 ton ha' ${ }^{-1}$.

Jagung ketan merupakan salah satu komoditas hortikultura yang memiliki kandungan amilopektin yang tinggi. Kandungan amilopektin yang tinggi menyebabkan tekstur jagung menjadi lunak dan pulen (Widowati et al., 2006). Wilayah yang menjadi sentra produksi jagung ketan di Indonesia yaitu Nusa Tenggara Barat (NTB), Nusa Tenggara Timur (NTT), Sulawesi Selatan, dan beberapa daerah di Papua (BPS, 2014). Sebagian besar wilayah tersebut adalah wilayah bagian timur Indonesia sehingga jagung ketan kurang dikenal di Pulau Jawa. Faktor yang menyebabkan jagung ketan sedikit dibudidayakan yaitu jagung ketan umumnya jagung lokal yang mempunyai potensi hasil rendah yaitu kurang dari 2 ton ha ${ }^{-1}$ (Rouf et al., 2010). Peningkatan produksi jagung ketan perlu untuk dilakukan seiring dengan meningkatnya permintaan terhadap jagung ketan.

Karakter unggul yang terdapat pada jagung manis dan jagung ketan mendorong pemulia untuk mengembangkan jagung ketan yang pulen dan memiliki kandungan gula yang tinggi serta memiliki produktivitas yang baik. Upaya yang dapat dilakukan untuk menggabungkan kedua karakter tersebut adalah melalui program pemuliaan tanaman. Keberhasilan suatu program pemuliaan tanaman ditentukan oleh adanya keragaman genetik yang luas (Azrai, 2004). Keragaman genetik merupakan syarat mutlak dalam keberhasilan suatu program pemuliaan tanaman (Sutjahjo et al., 2015). Keragaman merupakan sumber untuk mendapatkan informasi genetik pada karakter yang diamati. Tahapan awal yang harus dilakukan adalah melakukan evaluasi terhadap keragaman genetik jagung manis dan jagung ketan. Penelitian ini bertujuan untuk mengevaluasi keragaan karakter hortikultura dan potensi hasil dari genotipe jagung manis dan jagung ketan.

\section{METODE PENELITIAN}

Penelitian ini dilaksanakan di Kebun Percobaan Leuwikopo dan Laboratorium Pemuliaan Tanaman Departemen Agronomi dan Hortikultura, Fakultas Pertanian, IPB Dramaga Bogor pada bulan Januari sampai dengan Mei 2016. Lahan berada pada ketinggian $196 \mathrm{~m} \mathrm{dpl,}$ berjenis tanah latosol dengan curah hujan rata rata $556.8 \mathrm{~mm} /$ bulan.

Penelitian ini menggunakan rancangan augmented dengan faktor tunggal yaitu genotipe jagung. Materi genetik yang digunakan adalah 32 genotipe uji dan 6 genotipe pembanding. Genotipe uji terdiri dari 26 genotipe jagung ketan dan 6 genotipe jagung manis (Tabel 1). Genotipe pembanding terdiri dari 3 varietas jagung ketan (URI, Kumala, Victoria) dan 3 varietas hibrida jagung manis (Bonanza, Secada, Talenta). Genotipe pembanding diulang sebanyak 4 kali sementara genotipe uji tidak diulang, sehingga terdapat 56 satuan percobaan.

Tabel 1. Materi genetik yang digunakan dalam penelitian

\begin{tabular}{|c|c|c|c|c|}
\hline \multicolumn{4}{|c|}{ Genotipe uji jagung ketan } & \multirow{2}{*}{$\begin{array}{l}\text { Genotipe uji jagung manis } \\
\text { 1. SD } 2\end{array}$} \\
\hline 1. & JLP 11 & 10. JWP 123 & 19. JWP 223 & \\
\hline 2. & JLP 12 & 11. JWP 124 & 20. JWP 21 & 2. $\mathrm{SD} 3$ \\
\hline 3. & JLP 13 & 12. JWP 125 & 21. JWP 32 & 3. Golden \\
\hline 4. & JLP 14 & 13. JWP 126 & 22. JKP 1 & 4. Hawaii \\
\hline 5 . & JLP 15 & 14. JWP 127 & 23. JKP 2 & 5. Bimmo \\
\hline 6. & JLP 16 & 15. JWP 128 & 24. JLL 1 & 6. Baruna \\
\hline 7. & JLP 17 & 16. JWP 129 & 25. JLK 1 & \\
\hline 8 . & JWP 121 & JWP 221 & 26. JLK 2 & \\
\hline 9. & JWP 122 & 18 JWP 222 & & \\
\hline
\end{tabular}


Alat yang digunakan adalah alat pertanian konvensional (cangkul, kored, tugal, ajir, label), alat pengukuran dan pengamatan (meteran, jangka sorong, timbangan, mistar, kamera digital, alat tulis), dan alat persilangan (kertas sungkup, spidol, stapler, paper clip, plastik).

Pelaksanaan penelitian dimulai dengan persiapan lahan meliputi pembersihan gulma, penggemburan tanah, aplikasi 10 ton pupuk kandang ha ${ }^{-1}$ dan $300 \mathrm{~kg}$ kapur pertanian $\mathrm{ha}^{-1}$ serta perataan tanah. Luas lahan yang yang digunakan yaitu $200 \mathrm{~m}^{2}$. Lahan dibagi menjadi 4 petakan. Penanaman jagung dilakukan satu minggu setelah aplikasi kapur pertanian dan pupuk kandang. Setiap genotipe ditanam dalam satu plot baris dengan panjang baris $5 \mathrm{~m}$. Penanaman jagung dilakukan dengan cara ditugal dengan jarak tanam $75 \mathrm{~cm}$ x $20 \mathrm{~cm}$ dengan kebutuhan benih sebanyak satu buah per lubang tanam. Pengendalian hama dengan menggunakan aplikasi insektisida butiran berbahan aktif karbofuran dengan dosis $5 \mathrm{~kg} \mathrm{ha}^{-1}$. Penyulaman dilakukan pada 1 MST. Pemeliharaan meliputi pemupukan, pembumbunan, pengendalian gulma dan pengendalian hama dan penyakit. Pemupukan dilakukan saat tanaman berumur 1 MST dan 3 MST. Pupuk yang digunakan yaitu $300 \mathrm{~kg}$ urea ha-1, $200 \mathrm{~kg} \mathrm{SP}-36$ $\mathrm{ha}^{-1}$, dan $100 \mathrm{~kg} \mathrm{KCl} \mathrm{ha}^{-1}$. Pemupukan dilakukan dengan cara dialur pada jarak $8 \mathrm{~cm}$ dari lubang tanam dengan kedalaman $8-10 \mathrm{~cm}$. Pupuk urea diberikan setengah dosis rekomendasi pada saat 1 MST dan sisanya pada 3 MST. Pupuk SP-36 dan $\mathrm{KCl}$ diberikan satu dosis rekomendasi pada 1 MST. Pembumbunan dilakukan pada 4 MST. Penyerbukan sendiri (selfing) dilakukan pada 5 tanaman selain tanaman contoh di setiap plot baris saat berumur 48-52 HST. Pemanenan dilakukan pada saat tongkol sudah terisi sempurna yang ditandai oleh rambut tongkol berwarna coklat kehitaman dan mengering. Pemanenan dilakukan pada saat tanaman berumur 95-100 HST.

Pengamatan dilakukan terhadap peubah kuantitatif dan kualitatif sesuai panduan IBPGR (1991). Peubah kuantitatif yang diamati yaitu persentase tumbuh tanaman, umur berbunga jantan (umur anthesis), umur berbunga betina (umur silking), tinggi tanaman, tinggi letak tongkol, diameter batang, panjang tongkol, diameter tongkol, kadar kemanisan (brix), jumlah baris biji, jumlah biji, bobot tongkol, bobot biji, bobot 100 biji, jumlah biji per tongkol, dan produktivitas. Peubah kualitatif yang diamati yaitu skor susunan baris biji, skor ketahanan terhadap serangan bulai, skor warna biji, skor pengisian tongkol, dan skor penampilan kelobot.

Pengamatan dilakukan terhadap 5 tanaman contoh untuk semua peubah kuantitatif kecuali pada peubah produktivitas, persentase tumbuh tanaman, umur silking, umur anthesis, dan ASI (Anthesis Silking Interval) dan semua peubah kualitatif kecuali skor ketahanan terhadap penyakit bulai. Penentuan skor susunan baris biji menurut CYMMIT (1994) meliputi (1) regular; (2) irregular; (3) straight, (4) spiral. Penentuan skor ketahanan terhadap serangan bulai menurut Muls et al. (2013) meliputi (1) sangat tahan, (2) tahan, (3) agak tahan, (4) peka, (5) sangat peka. Penentuan skor warna biji meliputi (1) putih, (2) kuning, (3) kuning tua, (4) oranye, (5) oranye tua. Penentuan skor pengisian tongkol dan penampilan kelobot meliputi (1) sangat baik, (2) baik, (3) cukup, (4) jelek, (5) sangat jelek (Azrai, 2004).

Data yang diperoleh dianalisis dengan uji $F$ untuk melihat ada atau tidaknya pengaruh antar genotipe uji. Tahap berikutnya adalah perhitungan nilai rata-rata tersesuaikan (adjusted mean) untuk tiap genotipe. Nilai rata-rata tersesuaikan tiap genotipe selanjutnya diuji lanjut menggunakan BNT 0,05 untuk membandingkan nilai rata-rata tersesuaikan tiap genotipe terhadap rataan umum. Analisis korelasi digunakan untuk melihat hubungan antarkarakter yang diamati dalam percobaan. Analisis data dilakukan dengan menggunakan perangkat lunak SAS 9.1, Minitab, dan Microsoft Excel 2007.

\section{HASIL DAN PEMBAHASAN}

\section{Kondisi Umum}

Penanaman dilakukan di Kebun Percobaan Leuwikopo, Kampus IPB Dramaga, Bogor pada bulan Januari - April 2016. Curah hujan tertinggi pada saat penelitian dilakukan yaitu $644 \mathrm{~mm} / \mathrm{bulan}$ di bulan Maret, sedangkan curah hujan terendah yaitu $415 \mathrm{~mm} / \mathrm{bulan}$ di bulan Januari (BMKG, 2016). Berdasarkan data curah hujan tersebut, bulan Januari-April dapat digolongkan sebagai bulan basah. Hal ini sesuai dengan Kartasapoetra (2006) yang menyatakan bahwa penggolongan tanaman semusim mengikuti klasifikasi iklim Oldeman, bulan dengan curah hujan lebih dari $200 \mathrm{~mm}$ diklasifikasikan sebagai bulan basah, sedangkan bulan dengan curah hujan kurang dari $100 \mathrm{~mm}$ diklasifikasikan sebagai bulan kering. Menurut Koswara (1986), curah hujan rata-rata yang dibutuhkan oleh pertanaman jagung sebesar 100-125 mm/bulan. Curah hujan yang cukup tinggi dapat menyebabkan munculnya serangan penyakit yang disebabkan oleh cendawan dan terjadinya kerebahan pada tanaman jagung. Suhu harian berkisar $23.8-31.3{ }^{\circ} \mathrm{C}$. 
Keragaan Karakter Kuantitatif Genotipe Jagung

Karakter kuantitatif yang diamati terdiri dari karakter vegetatif dan generatif. Karakter vegetatif tanaman jagung diamati setelah muncul bunga jantan. Karakter generatif diamati setelah muncul bunga jantan dan bunga betina.

Analisis ragam dilakukan untuk mengetahui ada atau tidaknya pengaruh antar genotipe uji. Hasil rekapitulasi sidik ragam keragaan karakter kuantitatif genotipe jagung ditunjukkan pada Tabel 2. Tabel 2 menunjukkan bahwa faktor kelompok atau ulangan tidak berpengaruh nyata terhadap seluruh peubah pengamatan kecuali panjang tongkol. Adanya respon yang sama pada kelompok yang berbeda menunjukkan bahwa lingkungan pada lokasi penelitian bersifat homogen. Faktor genotipe berpengaruh nyata terhadap semua peubah karakter vegetatif dan generatif kecuali pada peubah ASI (Anthesis Silking Interval). Pengaruh yang nyata pada genotipe uji terdapat pada seluruh peubah pengamatan kecuali ASI (Anthesis
Silking Interval) dan diameter batang. Perbandingan antara genotipe uji terhadap genotipe pembanding menunjukkan pengaruh yang nyata pada sebagian besar peubah yang diamati, kecuali pada peubah umur silking, umur anthesis, dan ASI (Anthesis Silking Interval).

Nilai koefisien keragaman (KK) menunjukkan besarnya pengaruh lingkungan dan faktor lain yang tidak dapat dikendalikan dalam percobaan (Gomez dan Gomez, 1995). Nilai koefisien keragaman (KK) dari peubah kuantitatif yang diamati berkisar antara 0.31 hingga 29.52 . Nilai koefisien keragaman (KK) tertinggi terdapat pada peubah bobot biji yaitu $29.52 \%$. Nilai koefisien keragaman $(\mathrm{KK})$ terendah terdapat pada peubah produktivitas yaitu $0.31 \%$. Seluruh peubah pengamatan kuantitatif berada pada kisaran koefisien keragaman yang normal yaitu di bawah $30 \%$. Berdasarkan rekapitulasi nilai koefisien keragamanan, secara umum pengaruh lingkungan dan faktor lain masih dapat dikendalikan dalam percobaan.

Tabel 2. Hasil rekapitulasi sidik ragam keragaan agronomi genotipe jagung

\begin{tabular}{|c|c|c|c|c|c|c|}
\hline Peubah & KT Kelompok & KT Genotipe & $\begin{array}{c}\text { KT Genotipe } \\
\text { Pembanding (C) }\end{array}$ & $\begin{array}{c}\text { KT Genotipe } \\
\text { Uji (L) }\end{array}$ & KT L ve C & $\mathrm{KK}(\%)$ \\
\hline Daya tumbuh (\%) & $64.14^{\mathrm{tn}}$ & $776.12 * *$ & $2.906 .72 * *$ & $441.51 * *$ & $496.28 * *$ & 9.28 \\
\hline Umur silking (hari) & $2.15^{\mathrm{tn}}$ & $35.06 * *$ & $77.74 * *$ & $29.30 * *$ & $0.04^{\mathrm{tn}}$ & 3.02 \\
\hline $\begin{array}{l}\text { Umur anthesis } \\
\text { (hari) }\end{array}$ & $3.93^{\mathrm{tn}}$ & $33.82 * *$ & $67.14 * *$ & $29.52 * *$ & $0.54^{\text {tn }}$ & 3.08 \\
\hline ASI (hari) & $0.72^{\mathrm{tn}}$ & $0.76^{\mathrm{tn}}$ & $1.17^{\text {tn }}$ & $0.71 * *$ & $0.29^{\text {tn }}$ & 5.77 \\
\hline $\begin{array}{l}\text { Tinggi tanaman } \\
(\mathrm{cm})\end{array}$ & $9.89^{\mathrm{tn}}$ & $1837.37 * *$ & $4823.19 * *$ & $1090.87 * *$ & $9303.15 * *$ & 6.22 \\
\hline $\begin{array}{l}\text { Tinggi tongkol } \\
(\mathrm{cm})\end{array}$ & $49.09^{\text {tn }}$ & $940.24 * *$ & $2.732 .73 * *$ & $517.76 * *$ & $4652.08 * *$ & 9.63 \\
\hline $\begin{array}{l}\text { Diameter batang } \\
(\mathrm{mm})\end{array}$ & $8.79^{\text {tn }}$ & $7.71 * *$ & $23.38 * *$ & $4.78 * *$ & $17.41^{*}$ & 9.33 \\
\hline $\begin{array}{l}\text { Panjang tongkol } \\
\text { (cm) }\end{array}$ & $5.02^{*}$ & $15.17 * *$ & $21.77 * *$ & $10.01 * *$ & $137.27 * *$ & 9.54 \\
\hline $\begin{array}{l}\text { Diameter tongkol } \\
(\mathrm{mm})\end{array}$ & $3.22^{\text {tn }}$ & $59.37 * *$ & $90.54 * *$ & $31.99 * *$ & $724.93 * *$ & 7.99 \\
\hline Jumlah baris biji & $2.06^{\mathrm{tn}}$ & $8.79 * *$ & $24.45 * *$ & $3.47 * *$ & $89.99 * *$ & 7.08 \\
\hline $\begin{array}{l}\text { Bobot tongkol } \\
\text { (gram) }\end{array}$ & $871.22^{\mathrm{tn}}$ & $1557.87 * *$ & $2536.75 * *$ & $928.18 * *$ & $15554.07 * *$ & 28.76 \\
\hline Bobot biji (gram) & $605.10^{\mathrm{tn}}$ & $1122.63 * *$ & $1638.00 * *$ & $845.15 * *$ & $6870.27 * *$ & 29.52 \\
\hline $\begin{array}{l}\text { Bobot } 100 \text { biji } \\
(\text { gram })\end{array}$ & $6.41^{\text {tn }}$ & $145.08 * *$ & $68.85 * *$ & $152.73 * *$ & $296.53 * *$ & 20.83 \\
\hline Kadar gula (Brix) & $0.18^{\mathrm{tn}}$ & $8.30 * *$ & $19.32 * *$ & $3.10 * *$ & $109.18^{\mathrm{tn}}$ & 7.75 \\
\hline Jumlah biji (butir) & $6752.16^{\text {tn }}$ & $29781.98 * *$ & $79180.56 * *$ & $9609.53 * *$ & $408.13 * *$ & 18.51 \\
\hline $\begin{array}{l}\text { Produktivitas } \\
\left.\left(\text { ton }^{-1}\right)^{-1}\right)\end{array}$ & $0.0001 \mathrm{tn}$ & $3.42 * *$ & $6.23 * *$ & $1.82 * *$ & $37.55 * *$ & 0.31 \\
\hline
\end{tabular}


Pengaruh nyata antara genotipe uji dan genotipe pembanding dijelaskan dengan menyajikan perbandingan nilai rata-rata genotipe untuk tiap peubah kuantitatif. Tabel 3 menunjukkan perbedaan yang nyata untuk beberapa karakter. Genotipe pembanding jagung ketan memiliki nilai yang nyata lebih tinggi pada karakter bobot biji dan produktivitas. Hal ini menunjukkan bahwa kelompok genotipe uji jagung ketan masih memiliki produktivitas yang rendah.

Genotipe uji jagung manis menunjukkan nilai yang tidak berbeda nyata secara statistik dengan genotipe pembanding pada karakter bobot biji dan produktivitas. Genotipe pembanding pada jagung manis nyata lebih unggul dalam karakter bobot biji dan produktivitas. Hal ini menunjukkan bahwa kelompok genotipe uji jagung manis masih memiliki produktivitas yang rendah. Genotipe pembanding jagung manis yang digunakan adalah varietas hibrida. Kutka (2011) menyatakan bahwa penggunaan jagung hibrida mampu memberikan hasil panen hingga dua kali lebih tinggi dibandingkan varietas bersari bebas. Produksi jagung manis hibrida lebih unggul dibandingkan jagung manis bersari bebas (jagung lokal) karena jagung hibrida merupakan hasil persilangan dari tetua-tetua yang unggul dengan memanfaatkan sifat heterosis dari tetua-tetuanya (Putra et al., 2008).

Tabel 3. Nilai rata-rata tiap peubah berdasarkan kelompok genotipe jagung

\begin{tabular}{|c|c|c|c|c|c|}
\hline \multirow{2}{*}{ Peubah } & \multicolumn{2}{|c|}{ Jagung Ketan } & \multicolumn{2}{|c|}{ Jagung Manis } & \multirow{2}{*}{ BNT 0.05} \\
\hline & Genotipe uji & Pembanding & Genotipe uji & Pembanding & \\
\hline Daya tumbuh (\%) & $92.92^{\mathrm{a}}$ & $88.3^{\mathrm{a}}$ & $81.75^{\mathrm{a}}$ & $93.54^{\mathrm{a}}$ & 23.30 \\
\hline Umur anthesis (hari) & $46.65^{\mathrm{a}}$ & $43.5^{\mathrm{a}}$ & $49.50^{\mathrm{a}}$ & $50.50^{\mathrm{a}}$ & 4.28 \\
\hline Umur silking (hari) & $50.47^{\mathrm{a}}$ & $47.1^{\mathrm{a}}$ & $53.53^{\mathrm{a}}$ & $54.92^{\mathrm{a}}$ & 4.59 \\
\hline Tinggi tanaman $(\mathrm{cm})$ & $209.32^{\mathrm{a}}$ & $184.4^{\mathrm{a}}$ & $186.42^{\mathrm{a}}$ & $185.88^{\mathrm{a}}$ & 36.90 \\
\hline Tinggi tongkol (cm) & $108.08^{\mathrm{a}}$ & $89.0^{\mathrm{a}}$ & $92.29^{\mathrm{a}}$ & $90.62^{a}$ & 28.66 \\
\hline Diameter tanaman $(\mathrm{mm})$ & $16.57^{\mathrm{a}}$ & $18.2^{\mathrm{a}}$ & $16.31^{\mathrm{a}}$ & $18.03^{\mathrm{a}}$ & 13.20 \\
\hline Bobot tongkol (gram) & $49.59^{\mathrm{a}}$ & $75.0^{\mathrm{a}}$ & $77.00^{\mathrm{a}}$ & $95.22^{\mathrm{a}}$ & 56.43 \\
\hline Panjang tongkol (gram) & $10.34^{\mathrm{a}}$ & $13.2^{\mathrm{a}}$ & $13.96^{\mathrm{a}}$ & $15.79^{\mathrm{a}}$ & 3.60 \\
\hline Diameter tongkol(mm) & $30.80^{\mathrm{a}}$ & $37.4^{\mathrm{a}}$ & $38.77^{\mathrm{a}}$ & $44.03^{\mathrm{a}}$ & 8.67 \\
\hline Jumlah baris biji & $10.03^{\mathrm{a}}$ & $11.9^{\mathrm{a}}$ & $12.95^{\mathrm{a}}$ & $15.05^{\mathrm{a}}$ & 2.53 \\
\hline Bobot biji (gram) & $35.84^{\mathrm{b}}$ & $63.1^{\mathrm{a}}$ & $55.78^{\mathrm{b}}$ & $72.73^{\mathrm{a}}$ & 13.42 \\
\hline Bobot 100 biji (gram) & $21.57^{\mathrm{a}}$ & $22.5^{\mathrm{a}}$ & $15.60^{\mathrm{a}}$ & $15.78^{a}$ & 13.42 \\
\hline Jumlah biji & $156.43^{\mathrm{a}}$ & $279.7^{\mathrm{a}}$ & $341.61^{\mathrm{a}}$ & $454.67^{\mathrm{a}}$ & 146.99 \\
\hline Produktivitas (ton $\mathrm{ha}^{-1}$ ) & $2.22^{\mathrm{b}}$ & $3.8^{\mathrm{a}}$ & $3.44^{\mathrm{b}}$ & $4.45^{\mathrm{a}}$ & 0.03 \\
\hline Kadar gula (brix) & $8.48^{\mathrm{a}}$ & $10.1^{\mathrm{a}}$ & $12.50^{\mathrm{a}}$ & $14.03^{\mathrm{a}}$ & 2.40 \\
\hline
\end{tabular}

Keterangan : Nilai yang diikuti huruf yang sama pada baris yang sama tidak berbeda nyata menurut uji BNT 5\%

\section{Analisis Koefisien Korelasi Linier Antar Karakter}

Tabel 4. Korelasi linier antar karakter kuantitatif genotipe jagung

\begin{tabular}{|c|c|c|c|c|c|c|c|c|c|}
\hline & UA & US & TT & Ttong & Dtan & Ptong & Dtong & Btong & Prod \\
\hline US & $0.98^{* * *}$ & & & & & & & & \\
\hline $\mathrm{TT}$ & $-0.05^{\mathrm{tn}}$ & $-0.06^{\mathrm{tn}}$ & & & & & & & \\
\hline Ttong & $0.02^{\text {tn }}$ & $0.02^{\text {tn }}$ & $0.93^{* *}$ & & & & & & \\
\hline Dtan & $-0.15^{\text {tn }}$ & $-0.16^{\mathrm{tn}}$ & $0.84^{* *}$ & $0.77^{* *}$ & & & & & \\
\hline Ptong & $0.31^{*}$ & $0.31^{*}$ & $0.54^{* *}$ & $0.48^{* *}$ & $0.65^{\text {** }}$ & & & & \\
\hline Dtong & $0.06^{\mathrm{tn}}$ & $0.05^{\mathrm{tn}}$ & $0.54^{* *}$ & $0.43^{\text {** }}$ & $0.73^{\text {** }}$ & $0.85^{* *}$ & & & \\
\hline Btong & $0.17^{\text {tn }}$ & $0.16^{\mathrm{tn}}$ & $0.43^{\text {** }}$ & $0.41^{* * *}$ & $0.54^{\text {** }}$ & $0.86^{* *}$ & $0.80^{* *}$ & & \\
\hline Prod & $0.11^{\text {tn }}$ & $0.08^{\mathrm{tn}}$ & $0.40^{\text {** }}$ & $0.38 *$ & $0.63^{\text {** }}$ & $0.72^{* *}$ & $0.69^{\text {** }}$ & $0.70^{\text {** }}$ & \\
\hline Bbiji & $0.09^{\text {tn }}$ & $0.07^{\text {tn }}$ & $0.41^{\text {** }}$ & $0.37 *$ & $0.61^{* *}$ & $0.79^{\text {** }}$ & $0.81^{\text {** }}$ & $0.88^{* *}$ & $0.92^{* *}$ \\
\hline
\end{tabular}

Keterangan : $*$ = berpengaruh nyata pada taraf $5 \%, * *=$ berpengaruh nyata pada taraf $1 \%, \mathrm{tn}=$ tidak berpengaruh nyata, UA $=$ umur anthesis, US $=$ umur silking, TT $=$ tinggi tanaman, Ttong $=$ tinggi letak tongkol, Dtan $=$ diameter tanaman, Ptong $=$ panjang tongkol, Dtong $=$ diameter tongkol, Btong $=$ bobot tongkol, Prod $=$ produktivitas pipilan kering, Bbiji $=$ Bobot biji per tongkol.

Analisis korelasi digunakan untuk mengukur kekuatan hubungan antara dua peubah melalui koefisien korelasi (Walpole, 1982). Menurut Matjik dan Sumertajaya (2006) koefisien korelasi dinotasikan menggunakan huruf $r$ dengan kisaran nilai $-1 \leq \mathrm{r} \geq 1$, nilai $\mathrm{r}$ mendekati 1 atau -1 semakin erat hubungannya dan nilai $r$ yang mendekati nol menunjukkan hubungan antar peubah semakin lemah. Nilai $r$ (1) menunjukkan bahwa kedua karakter berbanding lurus, 
sedangkan nilai $\mathrm{r} \quad(-1)$ menunjukkan kedua karakter berbanding terbalik. Perhitungan nilai koefisien korelasi diamati dari 10 karakter dan didapatkan 45 pasang nilai koefisien korelasi antarkarakter. Pasangan karakter yang memiliki keeratan nyata sebanyak 30 pasang, semua kombinasi memiliki keeratan hubungan yang berbanding lurus.

Berdasarkan Tabel 4 karakter umur anthesis berkorelasi nyata dan positif terhadap umur silking sebesar 0.98, artinya semakin genjah umur berbunga jantan maka semakin genjah umur berbunga betina. Tinggi tanaman berkorelasi nyata dan positif terhadap tinggi tongkol sebesar 0.93 , artinya semakin tinggi tanaman jagung maka letak tongkolnya juga semakin tinggi. Komponen hasil merupakan karakter yang penting dalam pemuliaan jagung. Terdapat korelasi positif yang sangat nyata antara panjang tongkol, diameter tongkol, bobot tongkol, dan bobot biji per tongkol terhadap produktivitas yang berturut-turut nilai koefisien korelasinya adalah $0.72,0.69,0.70$, dan
0.92. Korelasi positif yang nyata juga terdapat pada karakter tinggi tanaman dan tinggi tongkol terhadap bobot biji per tongkol $\left(\mathrm{r}=0.41^{* *}\right.$ dan $\mathrm{r}=$ $\left.0.37^{*}\right)$. Hal ini menunjukkan bahwa bertambahnya tinggi tanaman dan tinggi tongkol akan diikuti oleh respon bertambahnya bobot biji per tongkol. Hasil penelitian Bara (2009) menunjukkan bahwa semakin tinggi tanaman, jumlah daun semakin banyak. Menurut Gardner et al. (2008), tanaman yang memiliki jumlah daun yang lebih banyak memiliki peluang untuk menangkap dan memanfaatkan energi matahari yang lebih banyak dalam proses fotosintesis untuk memproduksi fotosintat.

\section{Karakter Agronomi dan Daya Hasil}

Keragaan genotipe jagung uji dapat dianalisis menggunakan pendekatan karakter kuantitatif agronomi. Karakter tersebut antara lain tinggi tanaman, panjang tongkol, diameter tongkol, bobot tongkol, dan produktivitas.

Tabel 5. Rekapitulasi nilai rata-rata tiap karakter pada genotipe jagung ketan

\begin{tabular}{|c|c|c|c|c|c|}
\hline Genotipe & $\begin{array}{l}\text { Tinggi tanaman } \\
\text { (cm) }\end{array}$ & $\begin{array}{l}\text { Panjang tongkol } \\
(\mathrm{cm})\end{array}$ & $\begin{array}{c}\text { Diameter } \\
\text { tongkol }(\mathrm{cm})\end{array}$ & $\begin{array}{l}\text { Bobot tongkol } \\
\text { (gram) }\end{array}$ & $\begin{array}{c}\text { Prod } \\
\left.\left(\text { ton }^{-1}\right)^{-1}\right)\end{array}$ \\
\hline JLP11 & 209.97 uk & 9.39 & 29.67 & 44.52 & 2.40 \\
\hline JLP12 & $194.36 \mathrm{uk}$ & 8.71 & 32.23 & 30.40 & 1.56 \\
\hline JLP13 & $207.16 \mathrm{uk}$ & 9.91 & 31.21 & 38.99 & 1.97 \\
\hline JLP14 & 180.77 & 9.71 & 32.05 & 43.60 & 2.25 \\
\hline JLP15 & $202.11 \mathrm{uk}$ & 9.02 & 30.98 & 50.10 & 2.51 \\
\hline JLP16 & $215.76 \mathrm{uk}$ & 12.27 & 33.05 & 56.89 & $2.74 \mathrm{k}$ \\
\hline JLP17 & $207.36 \mathrm{uk}$ & 8.00 & 23.83 & 0.09 & 1.51 \\
\hline JWP121 & $222.36 \mathrm{uk}$ & 10.05 & 28.95 & 15.77 & 0.74 \\
\hline JWP122 & $196.37 \mathrm{uk}$ & 10.55 & 26.77 & 41.38 & 2.21 \\
\hline JWP123 & $192.96 \mathrm{uk}$ & 6.36 & 27.10 & 71.07 & 0.46 \\
\hline JWP124 & $227.91 \mathrm{uk}$ & 8.98 & 29.53 & 39.45 & 1.99 \\
\hline JWP125 & 179.17 & 8.97 & 27.01 & 35.14 & 2.16 \\
\hline JWP126 & $189.56 \mathrm{u}$ & 9.61 & 30.22 & 36.80 & 2.14 \\
\hline JWP127 & $227.36 \mathrm{uk}$ & 10.53 & 32.43 & 55.02 & $2.92 \mathrm{k}$ \\
\hline JWP128 & $215.31 \mathrm{uk}$ & 9.20 & 31.35 & 46.63 & 2.35 \\
\hline JWP129 & $251.11 \mathrm{uk}$ & 10.52 & 32.88 & 49.39 & 2.47 \\
\hline JWP221 & $222.36 \mathrm{uk}$ & 8.10 & 29.92 & 22.13 & 1.15 \\
\hline JWP222 & 162.16 & 7.88 & 31.60 & 20.97 & 1.08 \\
\hline JWP223 & $250.16 \mathrm{uk}$ & 11.54 & 34.10 & 54.63 & $2.87 \mathrm{k}$ \\
\hline JWP21 & $226.57 \mathrm{uk}$ & 10.83 & 36.44 & 71.34 & $3.63 \mathrm{k}$ \\
\hline JWP32 & $223.71 \mathrm{uk}$ & 10.04 & 31.97 & 51.19 & $2.80 \mathrm{k}$ \\
\hline JKP2 & $303.31 \mathrm{uk}$ & $18.36 \mathrm{ukv}$ & $44.88 \mathrm{k}$ & $148.03 \mathrm{uk}$ & $6.99 \mathrm{ukv}$ \\
\hline JLL1 & 226.57 uk & 13.07 & 34.09 & 65.94 & $3.41 \mathrm{k}$ \\
\hline JLK1 & $270.57 \mathrm{ukv}$ & $18.91 \mathrm{ukv}$ & 32.98 & 87.88 & 2.26 \\
\hline JLK2 & $242.36 \mathrm{uk}$ & $17.49 \mathrm{ukv}$ & $46.53 \mathrm{uk}$ & 16.86 & 1.04 \\
\hline URI & 164.25 & 12.00 & 36.36 & 75.89 & 3.95 \\
\hline Kumala & 163.66 & 14.10 & 35.83 & 52.69 & 2.56 \\
\hline Victoria & 225.60 & 13.73 & 40.12 & 96.50 & 5.15 \\
\hline BNT 0,05 & 28.66 & 3.60 & 8.67 & 56.43 & 0.03 \\
\hline
\end{tabular}

Keterangan : Prod $=$ produktivitas pipilan kering, angka yang diikuti huruf $\mathrm{U}, \mathrm{K}, \mathrm{V}$ masing-masing nyata lebih tinggi dari pembanding $\mathrm{U}=\mathrm{URI}, \mathrm{K}=$ Kumala, $\mathrm{V}=$ Victoria

Secara umum, keragaan agronomi genotipe uji jagung ketan yang memiliki tinggi tanaman yang nyata lebih tinggi dibandingkan genotipe pembanding URI dan Kumala yaitu 
genotipe JLP11, JLP12, JLP13, JLP15, JLP16, JLP17, JWP121, JWP122, JWP123, JWP124, JWP127, JWP128, JWP129, JWP221, JWP223, JWP21, JWP32, JKP2, JLL1, dan JLK2. Genotipe JWP126 memiliki tinggi tanaman yang nyata lebih tinggi dibandingkan genotipe pembanding URI. Genotipe JLK1 memiliki tinggi tanaman yang nyata lebih tinggi dibandingkan genotipe pembanding URI, Kumala, dan Victoria (Tabel 5).

Panjang tongkol pada genotipe JKP2, JLK1, dan JLK2 nyata lebih tinggi dibandingkan genotipe pembanding URI, Kumala, dan Victoria. Diameter tongkol pada genotipe JLK2 nyata lebih tinggi dibandingkan genotipe pembanding URI dan Kumala, sedangkan diameter tongkol genotipe JKP2 nyata lebih tinggi dibandingkan genotipe pembanding Kumala. Bobot tongkol pada genotipe JKP2 nyata lebih tinggi dibandingkan genotipe pembanding URI dan Kumala. Nilai produktivitas pada genotipe JKP2 nyata lebih tinggi dibandingkan genotipe pembanding URI, Kumala, dan Victoria. Genotipe yang memiliki nilai produktivitas yang nyata lebih tinggi dibandingkan genotipe pembanding Kumala yaitu JLP16, JWP127, JWP223, JWP21, JWP32, dan JLL1 (Tabel 5).

Tabel 6. Rekapitulasi nilai rata-rata tiap karakter pada genotipe jagung manis

\begin{tabular}{lccccc}
\hline \multirow{2}{*}{ Genotipe } & Tinggi tanaman & Panjang & Diameter & Bobot tongkol & Prod \\
\cline { 2 - 6 } & $(\mathrm{cm})$ & tongkol $(\mathrm{cm})$ & tongkol $(\mathrm{mm})$ & $($ gram $)$ & $\left(\right.$ ton ha $\left.^{-1}\right)$ \\
\hline SD2 & $180.71 \mathrm{~T}$ & 13.66 & 37.82 & 82.55 & 2.57 \\
SD3 & $193.36 \mathrm{~T}$ & 15.07 & 41.61 & 73.97 & $3.40^{\mathrm{T}}$ \\
Golden & 113.16 & 10.47 & 27.86 & 15.36 & 0.64 \\
Hawaii & $218.36 \mathrm{~T}$ & 13.58 & 41.18 & 90.29 & $4.20^{\mathrm{T}}$ \\
Bimmo & $223.51 \mathrm{~T}$ & 14.62 & 42.54 & 78.85 & $3.61^{\mathrm{T}}$ \\
Baruna & $189.97 \mathrm{~T}$ & $16.27 \mathrm{~T}$ & 43.15 & $124.16 \mathrm{~T}$ & $6.24^{\mathrm{BST}}$ \\
\hline Bonanza & 198.65 & 17.61 & 45.19 & 117.86 & 5.30 \\
Secada & 219.80 & 17.15 & 47.64 & 104.26 & 5.26 \\
Talenta & 139.20 & 12.61 & 39.29 & 63.52 & 2.80 \\
\hline BNT 0.05 & 28.66 & 3.60 & 8.67 & 56.43 & 0.03 \\
\hline
\end{tabular}

Keterangan : Prod = produktivitas pipilan kering, angka yang diikuti huruf B, S, T masing-masing nyata lebih tinggi dari pembanding $\mathrm{B}=$ Bonanza, $\mathrm{S}=$ Secada, dan $\mathrm{T}=$ Talenta

Berdasarkan Tabel 6, genotipe SD2, SD3, Hawaii, Bimmo, dan Baruna memiliki tinggi tanaman yang nyata lebih tinggi dibandingkan genotipe pembanding Talenta. Genotipe Baruna memiliki panjang tongkol dan bobot tongkol yang nyata lebih tinggi dibandingkan genotipe pembanding Talenta. Genotipe SD3, Hawaii, dan Bimmo memiliki produktivitas yang nyata lebih tinggi dibandingkan genotipe pembanding Talenta. Produktivitas pada genotipe Baruna nyata lebih tinggi dibandingkan genotipe pembanding Bonanza, Secada, dan Talenta.

\section{Karakter Kualitatif}

Keragaan karakter kualitatif yang diamati meliputi warna biji, skor ketahanan bulai, penutupan kelobot, pengisian tongkol, dan susunan baris biji (Tabel 7). Secara umum, genotipe jagung ketan (genotipe uji dan pembanding) memiliki warna biji yang putih, sedangkan genotipe uji jagung manis berwarna oranye hingga oranye tua, dan pembanding jagung manis berwarna kuning hingga kuning tua. Intensitas warna kuning hingga oranye pada biji jagung mengindikasikan adanya kandungan karetonoid pada biji jagung, sedangkan biji jagung yang berwarna putih tidak mengandung karetonoid (Suarni dan Widowati, 2007).

Berdasarkan skor ketahanan terhadap penyakit bulai (Tabel 6), genotipe uji dan genotipe pembanding memiliki tingkat ketahanan bulai dari peka hingga sangat tahan. Genotipe yang peka terhadap penyakit bulai yaitu Golden yang merupakan varietas bersari bebas sebagai genotipe uji dan Kumala yang merupakan hibrida jagung ketan sebagai genotipe pembanding. Menurut Hoerussalam et al. (2013), ketahanan terhadap penyakit merupakan salah satu sifat yang sangat penting dalam pemuliaan tanman karena mempengaruhi kualitas dan tingkat produksi.

Karakter penutupan kelobot dinilai dengan metode skoring. Penilaian penutupan kelobot diberi skor dengan nilai 1 (sangat baik) jika kelobot menutup rapat sehingga beberapa tongkol dapat diikat menjadi satu pada ujung tongkol hingga nilai 5 (sangat jelek) jika kelobot terbuka sehingga sebagian biji nampak tidak dilindungi kelobot (CIMMYT, 1994). Berdasarkan kriteria tersebut, genotipe uji (galur jagung ketan) memiliki kelobot yang tergolong baik dengan kriteria kelobot menutup ketat hanya samapai di ujung tongkol hingga sangat baik dengan kriteria kelobot menutup rapat dengan baik, sehingga beberapa tongkol dapat diikat 
menjadi satu pada ujung tongkol. Penutupan kelobot pada genotipe uji (varietas bersari bebas jagung manis) relatif sama dengan genotipe pembanding (hibrida jagung manis dan pembanding jagung ketan).

Secara umum susunan baris biji pada genotipe uji (galur jagung ketan dan varietas bersari bersari bebas jagung manis) yaitu irregular. Susunan baris biji pada genotipe pembanding jagung manis yaitu straight, sedangkan pada varietas pembanding jagung ketan yaitu irregular.

Tabel 7. Rekapitulasi hasil pengamatan kualitatif genotipe jagung

\begin{tabular}{|c|c|c|c|c|c|}
\hline Genotipe & Warna biji & $\begin{array}{c}\text { Ketahanan } \\
\text { bulai }\end{array}$ & $\begin{array}{c}\text { Penutupan } \\
\text { kelobot }\end{array}$ & $\begin{array}{c}\text { Pengisian } \\
\text { tongkol }\end{array}$ & $\begin{array}{l}\text { Susunan } \\
\text { baris biji }\end{array}$ \\
\hline \multicolumn{6}{|c|}{ Genotipe uji jagung ketan } \\
\hline JLP11 & Putih & Tahan & Sangat baik & Baik & Spiral \\
\hline JLP12 & Oranye & Tahan & Baik & Cukup & Irregular \\
\hline JLP13 & Putih & Agak tahan & Sangat baik & Baik & Straight \\
\hline JLP14 & Putih & Tahan & Baik & Baik & Irregular \\
\hline JLP15 & Putih & Sangat tahan & Sangat baik & Baik & Irregular \\
\hline JLP16 & Putih & Tahan & Sangat baik & Baik & Straight \\
\hline JLP17 & Putih & Sangat tahan & Sangat baik & Sangat baik & Irregular \\
\hline JWP121 & Putih & Tahan & Sangat baik & Sangat baik & Irregular \\
\hline JWP122 & Putih & Tahan & Baik & Sangat baik & Irregular \\
\hline JWP123 & Putih & Tahan & Baik & Sangat baik & Irregular \\
\hline JWP124 & Kuning & Agak tahan & Sangat baik & Sangat baik & Irregular \\
\hline JWP125 & Putih & Agak tahan & Baik & Sangat jelek & Irregular \\
\hline JWP126 & Putih & Sangat tahan & Sangat baik & Baik & Irregular \\
\hline JWP127 & Putih & Sangat tahan & Baik & Cukup & Irregular \\
\hline JWP128 & Putih & Sangat tahan & Baik & Baik & Irregular \\
\hline JWP129 & Putih & Sangat tahan & Sangat baik & Baik & Irregular \\
\hline JWP221 & Putih & Sangat tahan & Sangat baik & Baik & Irregular \\
\hline JWP222 & Putih & Agak tahan & Baik & Baik & Irregular \\
\hline JWP223 & Putih & Sangat tahan & Sangat baik & Cukup & Spiral \\
\hline JWP21 & Putih & Sangat tahan & Sangat baik & Baik & Straight \\
\hline JWP32 & Putih & Sangat tahan & Sangat baik & Sangat baik & Irregular \\
\hline JKP1 & Putih & Agak tahan & Baik & Baik & Spiral \\
\hline JKP2 & Putih & Tahan & Baik & Cukup & Irregular \\
\hline JLL1 & Putih & Sangat tahan & Baik & Baik & Irregular \\
\hline JLK1 & Kuning & Sangat tahan & Baik & Cukup & Spiral \\
\hline JLK2 & Oranye tua & Agak tahan & Sangat baik & Sangat baik & Straight \\
\hline \multicolumn{6}{|c|}{ Genotipe pembanding jagung ketan } \\
\hline URI & Putih & Sangat tahan & Baik & Baik & Irregular \\
\hline Kumala & Putih & Peka & Baik & Cukup & Irregular \\
\hline Victoria & Putih & Sangat tahan & Sangat baik & Sangat baik & Straight \\
\hline \multicolumn{6}{|c|}{ Genotipe uji jagung manis } \\
\hline SD2 & Oranye & Sangat tahan & Cukup & Baik & Straight \\
\hline SD3 & Oranye & Agak tahan & Cukup & Cukup & Straight \\
\hline Golden & Oranye & Peka & Cukup & Baik & Irregular \\
\hline Hawaii & Oranye tua & Tahan & Sangat baik & Baik & Irregular \\
\hline Bimmo & Oranye & Sangat tahan & Baik & Cukup & Straight \\
\hline Baruna & Oranye & Tahan & Baik & Cukup & Regular \\
\hline \multicolumn{6}{|c|}{ Genotipe pembanding jagung manis } \\
\hline Bonanza & Kuning tua & Sangat tahan & Cukup & Sangat baik & Straight \\
\hline Secada & Kuning & Sangat tahan & Sangat baik & Sangat baik & Straight \\
\hline Talenta & Kuning & Tahan & Baik & Baik & Spiral \\
\hline
\end{tabular}

\section{KESIMPULAN}

Genotipe jagung ketan dan jagung manis yang diuji menunjukkan keragaman karakter hortikultura pada sebagian besar karakter yang diamati kecuali pada ASI (Anthesis Silking Interval). Terdapat korelasi positif yang sangat nyata antara panjang tongkol, diameter tongkol, bobot tongkol, dan bobot biji per tongkol terhadap produktivitas. Karakter tinggi tanaman dan tinggi 
tongkol berkorelasi positif dengan bobot biji per tongkol. Genotipe jagung ketan yang memiliki karakter hortikultura yang baik dan memiliki produktivitas yang lebih tinggi adalah JLP16, JWP127, JWP223, JWP21, JWP32, JKP2, dan JLL1. Genotipe jagung manis yang memiliki karakter hortikultura yang baik dan memiliki produktivitas yang lebih tinggi adalah SD3. Genotipe - genotipe tersebut memiliki skor yang baik untuk karakter ketahanan terhadap serangan bulai, karakter penutupan kelobot, dan karakter pengisian tongkol.

\section{DAFTAR PUSTAKA}

Azrai, M. 2004. Penampilan varietas jagung unggul baru bermutu protein tinggi di Jawa dan Bali. Bul.Plasma Nutfah 10 (2).

Bara, A. 2009. Pengaruh dosis pupuk kandang dan frekuensi pemberian pupuk urea terhadap pertumbuhan dan produksi jagung (Zea mays L.) di lahan kering. tesis. Institut Pertanian Bogor, Bogor.

[BMKG] Badan Meteorologi Klimatologi dan Geofisika. 2016. Data iklim tahun 2016. Stasiun Klimatologi Darmaga. Bogor.

[BPS] Badan Pusat Statistik. 2014. Produksi jagung menurut provinsi (ton) periode 1993-2013. $\quad$ \{www.bps.go.id $\}[14$ Desember 2015].

[BPS] Badan Pusat Statistik. 2015. Statistik ekspor impor komoditas pertanian 2001 2014. \{www.bps.go.id $\}[14$ Desember 2015].

[CYMMIT] International Maize and Wheat Improvement Center. 1994. Managing Trials and Reporting Data for CYMMIT's International Maize Testing Program. International Maize and Wheat Improvement Center, Mexico.

Gardner, F.P., Pearce, R.B., Mitchell, R.L. 2008. Fisiologi Tanaman Budidaya. Herawati S, penerjemah. UI Pr, Jakarta. Terjemahan dari : Physiology of crop Plants.

Gomez, K.A., A.A. Gomez. 1995. Prosedur Statistika untuk Percobaan Pertanian. Sjamsudin E dan Baharsjah JS, penerjemah. UI Pr, Jakarta. Terjemahan dari : Statistical Prosedures for Agricultural Research.
Hoerussalam, Purwantoro, A., Khaeruni, A. 2013. Induksi ketahanan jagung (Zea mays L.) terhadap penyakit bulai melalui seed treatment serta pewarisannya pada generasi S1. J. Ilmu Pertanian 16 : $42-59$.

[IBPGR] International Board for Plant Genetic Resource. 1991. Descriptors for Maize. IBPGR, Roma.

Kartasapoetra, A.G. 2006. Klimatologi : Pengaruh Iklim terhadap Tanah dan Tanaman. Bumi Aksara, Jakarta.

Koswara, J. 1986. Jagung. Institut Pertanian Bogor, Bogor.

Kutka, F. 2011. Open pollinated vs hybrid maize cultivars. Sustainability 3 : $1531-1554$.

Matjik, A.H., Sumertajaya, I.M. 2006. Perancangan Percobaan dengan Aplikasi SAS dan Minitab. IPB Pr, Bogor.

Muhsanati, Syarif, Rahayu. 2006. Pengaruh beberapa takaran kompos Tithonia terhadap pertumbuhan dan hasil tanaman jagung manis (Zea mays saccharata Sturt.). J.Jerami 1 (2) : 87-91.

Muls, A., Nanci, N., Pabendon, M.B. Skrining galur/varietas lokal jagung terhadap penyakit bulai . Seminar Nasional Serealia. 27-28 Juli 2013, Maros, Indonesia. Balai Penelitian Tanaman Serealia, Maros.

Putra, R.Y., Kumar, B., Ruswandi, D. 2008. Daya gabung umum galur-galur jagung manis di Jawa Barat. Zuriat 19 (2) : 210-217.

Rouf, A.A., A. Zubair D., Walangadi, M.Y., Antu, Sukarto. 2010. Pengkajian pemurnian benih jagung pulut di provinsi Gorontalo. Prosiding Pekan Serealia Nasional. Gorontalo.

Suarni, Widowati, S. 2007. Struktur, komposisi, dan nutrisi jagung. Dalam Jagung. Pusat Penelitian Tanaman Pangan, Bogor.

Sutjahjo, S.H., Herison, C., Sulastrini, I., Marwiyah, S. 2015. Pendugaan keragaman genetik beberapa karakter pertumbuhan dan hasil pada genotipe tomat lokal. J. Hort. Indonesia 25 (4) : 304-310. 
Syukur, M., Rifianto, A. 2013. Jagung Manis. Jakarta(ID): Penebar Swadaya.

Widowati, S., Santosa, S., Suarni. 2006. Mutu gizi dan sifat fungsional jagung. Prosiding seminar dan lokakarya nasional jagung. Pusat Penelitian Tanaman Pangan. Badan LitbangPertanian. 